\title{
Drying Kinetics of Poplar (Populus Delfoides) Wood Particles by a Convective Thin Layer Dryer
}

\section{Kinetika konvektivnog sušenja tankog sloja iverja drva topole (Populus Deltoides)}

Original scientific paper $\bullet$ Izvorni znanstveni rad

Received-prispjelo: 20. 1. 2012.

Accepted-prihvaćeno: 6. 9. 2012.

UDK: $630 * 847.5 ; 674.031 .623 .2 .5$

doi:10.5552/drind.2012.1201

\begin{abstract}
Drying of poplar wood (Populus Deltoides) particles was carried out at different drying conditions using a laboratory convective thin layer dryer. Drying curves were plotted and in order to analyze the drying behavior, the curves were fitted to different semi-theoretical drying kinetics models. The effective moisture diffusivity was also determined from the integrated Fick's second law equation and correlated with temperature using an Arrhenius- type model to calculate activation energy of diffusion. The results showed that Midilli et al. model was found to satisfactorily describe the drying characteristics of poplar wood particles dried at all temperatures and air flow velocities. In general, the drying rate increases with increasing air temperature and air flow velocity. A short constant drying rate period was observed and drying frequently took place at falling rate period in all cases. The effective moisture diffusivity of poplar wood particles increased from $1.01 \mathrm{E}-10$ to $2.53 \mathrm{E}-10 \mathrm{~m}^{2} \cdot \mathrm{s}^{-1}$ as the drying air temperature increased from 65 to $85^{\circ} \mathrm{C}$. The activation energy of diffusion for $1 \mathrm{~m} \cdot \mathrm{s}^{-1}$ and $1.5 \mathrm{~m} \cdot \mathrm{s}^{-1}$ air flow velocities were calculated as $27.8 \mathrm{~kJ} \cdot \mathrm{mol}^{-1}$ and $50.8 \mathrm{~kJ} \cdot \mathrm{mol}^{-1}$, respectively.
\end{abstract}

Key words: Poplar wood particles, thin layer dryer, drying kinetics model, effective moisture diffusivity, activation energy

SAŽETAK • Pri različitim uvjetima sušenja provedeno je sušenje iverja drva topole (Populus deltoides) uporabom konvektivne sušionice za tanki sloj iverja. Iscrtane su krivulje sušenja, a da bi se analizirao proces sušenja, krivulje su prilagođene različitim teorijskim kinetičkim modelima sušenja. Određena je i efektivna difuznost vode u drvu prema Fickovu drugom zakonu te je primjenom Arrheniusova modela za izračun aktivacijske energije difuzije korelirana s temperaturom. Rezultati su pokazali da model Midillija i suradnika zadovoljavajuće opisuje obilježja sušenja iverja drva topole pri svim temperaturama i brzinama strujanja zraka. U načelu, brzina sušenja povećava se s povećanjem temperature zraka i brzine strujanja zraka. Zabilježeno je kratko razdoblje konstantne brzine sušenja, a sušenje se najčešće postiže u razdoblju pada brzine sušenja. Efektivna difuzivnost vode u iverju drva topole povećana je s $1,01 \mathrm{E}-10 \mathrm{na}$ 2,53E-10 $\mathrm{m}^{2} \cdot \mathrm{s}^{-1} \mathrm{~s}$ povećanjem temperature zraka sa $65 \mathrm{na} 85^{\circ} \mathrm{C}$. Izračunana je aktivacijska energija difuzije za $1 \mathrm{~m} \cdot \mathrm{s}^{-1}$ i $1,5 \mathrm{~m} \cdot \mathrm{s}^{-1}$ brzine strujanja zraka i iznosi $27,8 \mathrm{~kJ} \cdot \mathrm{mol}^{-1}$ i $50,8 \mathrm{~kJ} \cdot \mathrm{mol}^{-1}$.

Ključne riječi: iverje drva topole, sušionica tankog sloja iverja, modeli kinetike sušenja, efektivna difuznost vode u drvu, aktivacijska energija

\footnotetext{
${ }^{1}$ Authors are PhD candidate, full professor and asssitant professor at Department of Wood and Paper Sciences and Technology, Faculty of Natural Resources, University of Tehran,Karaj, Iran.

' Autori su doktorand, profesor i docent Odjela za znanost i tehnologiju drva i papira, Fakultet prirodnih resursa, Sveučilište u Teheranu, Iran.
} 


\section{INTRODUCTION}

\section{UVOD}

In many developing countries, deforestation and over harvesting from poorly managed forests have brought environmental awareness. As a result, focus was placed on studies dealing with the use of implanted wood resources instead of local forest resources for wood composites production. Therefore, fast growing wood resources such as poplar wood are getting more important as a raw material in particleboard and other wood based panel manufacturing.

Drying of wood particles is one of the main steps in a particleboard production process. Consumption of a high amount of energy, apart from environmental impacts, makes it one of the most energy intensive operations with a great importance in particleboard manufacturing. Hence reducing energy consumption, besides product quality, would be highly important for drying the raw materials used in industry.

Investigation of drying kinetics is one of the best methods to get sufficient information about drying performance. Experimental data from the drying curves can be used in simulation of wood particle drying to optimize the particleboard production process.

Thin layer drying equations are important tools in mathematical modeling of drying. They are practical and give sufficiently good results. To use thin layer drying equations, the drying rate curves have to be known. Thin layer drying generally means to dry sample particles or slices in one layer (Akpinar, 2006). The drying performance of hygroscopic materials can be characterized by measuring the changes in the moisture content as a function of time. Drying kinetics data for wood chips in a steam dryer have been determined by Fyhr and Rasmuson (1996). Ceylan (2008) investigated the drying characteristic of poplar and pine timbers in a heat pump dryer, but there is no information available on thin layer drying of poplar wood particles. Laboratory based modeling is needed to characterize the thin layer drying process of poplar wood particles, as full scale studies are both expensive and time consuming (Ghazanfari et al., 2006). Therefore, the objectives of this study were to investigate the drying characteristics of poplar wood particles in a hot air convective thin layer dryer and fit the best model for the drying performance of poplar wood particles. In addition, the drying kinetics, moisture effective diffusivities, and activation energies of diffusion at different drying conditions will be computed.

\section{MATERIALS AND METHODS}

\section{MATERIJAL I METODE}

\subsection{Raw material}

2.1. Sirovina

The poplar wood (Populus Deltoides) used in this study was supplied from research and educational forest, Khyroudkenar, Noshahr (longitude: $51^{\circ} 31^{\prime}$, Altitude: $36^{\circ} 39^{\prime}$, latitude: $-20 \mathrm{~m}$ ), managed by University of Tehran, Iran. The 20 years old tree trunks were sliced and cut into long strands using an industrial slicer in Rokesh Choobi factory, Gazvin, Iran. The strands were cut into slice shape particles with approximate target dimensions of 1x20x30 mm using a laboratory clipper. The wood particles with the moisture content of around $0.2 \mathrm{~kg}$ water $/ \mathrm{kg}$ dry material were wetted by distilled water to around $1.6 \mathrm{~kg}$ water $/ \mathrm{kg}$ dry material and finally they were kept in sealed plastic bags and stored in a $0-4{ }^{\circ} \mathrm{C}$ refrigerator to reach equilibration of moisture content without deterioration, for 72 hours before drying.

\subsection{Drying procedure}

\subsection{Postupak sušenja}

The homogeneously moistened wood particles that had been stored in plastic bags, were placed and spread on three perforated trays, in one layer (about 20 $\mathrm{g}$ of dry wood particles on each tray), and put into hot air duct on digital balance, which was connected to a computer. Drying experiments were performed at hot air temperatures of 65,75 , and $85^{\circ} \mathrm{C}$ with air flow velocities of 1 and $1.5 \mathrm{~m} \cdot \mathrm{s}^{-1}$ in a laboratory-scale convective thin layer dryer. The initial weight of each sample was measured by an electronic digital balance (GF3000, \pm 0.02 , A\& D, Japan). The dryer was set to the selected drying temperatures and air flow velocities for about $30 \mathrm{~min}$ to achieve the steady-state conditions before the samples were placed in the duct. The temperatures were measured by means of LM35 sensor (LM35, \pm 1 ${ }^{\circ} \mathrm{C}$, NSC, USA), the air flow velocities were measured using an anemometer ( $\mathrm{V}$ - sensor, 405- VI, $\pm 3 \%$, TESTO, UK) and the relative humidity of fresh air was measured using a humidity probe (RH-sensor, Capacitive, $\pm 3 \%$, PHILIPS, UK). The relative humidity of fresh air was constant $(17 \%)$ throughout the experiments. The weight losses of the samples were measured and automatically recorded at 10 second intervals until equilibrium moisture content (EMC) was achieved. Finally, the dried poplar wood particles were put into an oven at $103 \pm 2{ }^{\circ} \mathrm{C}$ for getting equilibrium moisture content. The initial moisture content and equilibrium moisture content were calculated using ASAE, 2001 equations

\subsection{Mathematical modeling of drying and data analysis}

2.3. Matematičko modeliranje sušenja i analiza podataka

The form of Newton's law of cooling in heat transfer (equation 1) is often used to describe the moisture loss in thin layer drying (Brooker and Bakker- Arkema, 1974). Based on this law, the drying rate is proportional to the difference in moisture content between the material being dried and the equilibrium moisture content at the drying conditions as:

$$
\frac{d M}{d T}=-k\left(M-M_{e}\right)
$$

The solution of (1), assuming $k$ is independent of $M$ and $M_{e}$, is:

$$
M R_{\text {Newton }}=\exp (-k t)
$$


Where $M R$ is the dimensionless moisture ratio given by:

$$
M R=\frac{M-M_{e}}{M_{0}-M_{e}}
$$

In order to determine the moisture ratio as a function of drying time, drying curves obtained in this experiment were fitted with four different models of moisture ratio thin layer drying obtained from the literature (Table 1).

Table 1 Mathematical models applied to the drying curves Tablica 1. Matematički modeli primijenjeni za krivulje sušenja

\begin{tabular}{|l|l|l|}
\hline $\begin{array}{l}\text { Model name } \\
\text { Naziv modela }\end{array}$ & $\begin{array}{l}\text { Model equation } \\
\text { Jednadžba modela }\end{array}$ & $\begin{array}{l}\text { Reference } \\
\text { Referenca }\end{array}$ \\
\hline Newton & $M R=\exp (-k t)$ & $\begin{array}{l}\text { O'Callaghan } \text { et al., } \\
1971\end{array}$ \\
\hline Page & $M R=\exp \left(-k t^{n}\right)$ & Pang, 1949 \\
\hline $\begin{array}{l}\text { Henderson \& } \\
\text { Pabis }\end{array}$ & $M R=a \cdot \exp (-k t)$ & $\begin{array}{l}\text { Guarte, 1996; } \\
\text { Chninman, 1984 }\end{array}$ \\
\hline Midilli et al. & $M R=a \cdot \exp \left(-k t^{n}\right)+b t$ & Midilli et al., 2002 \\
\hline
\end{tabular}

The goodness of fit of each model to the experimental data was evaluated from the coefficient of determination $\left(R^{2}\right)$, root mean square error $(R M S E)$, reduced chi-square $\left(\chi^{2}\right)$, and mean bias error $(M B E)$. $R^{2}$ was used as the primary comparison criteria for selecting the best model to fit the four models to the experimental data. Also, a model is considered better than another if it has a lower value of the MBE, RMSE, and $\chi^{2}$. The expressions for each of these parameters are stated as follows:

$R^{2}=\frac{\sum_{i=1}^{N}\left(M_{R_{i}}-M_{R_{p r e, i}}\right) *\left(M_{R_{i}}-M_{R_{\text {exp }, i}}\right)}{\sqrt{\left[\left(\sum_{i=1}^{N}\left(M_{R_{i}}-M_{R_{p r e, i}}\right)^{2}\right) *\left(\sum_{i=1}^{N}\left(M_{R_{i}}-M_{R_{e x p}, i}\right)^{2}\right)\right]}}$

$\chi^{2}=\frac{\sum_{i=1}^{N}\left(M_{R_{\mathrm{exp}, i}}-M_{R_{p r e, i}}\right)^{2}}{N-n}$

$R M S E=\left[\frac{1}{N} \sum_{i=1}^{N}\left(M_{R_{p r e, i}}-M_{R_{\mathrm{exp}, i}}\right)\right]^{\frac{1}{2}}$

$M B E=\frac{1}{N} \sum_{i=1}^{N}\left(M_{R_{p r e, i}}-M_{R_{\text {exp }, i}}\right)$

The $M B E$ provides information on the long term performance of the correlations by allowing a comparison of the actual deviation between predicted and measured values term by term. The ideal value of $M B E$ is 'zero'.

\section{RESULTS AND DISCUSSION}

\section{REZULTATI I RASPRAVA}

\subsection{Experiments of drying kinetics}

\subsection{Eksperimenti kinetike sušenja}

Drying curves for the different temperatures and velocities of hot air in drying poplar wood particles are

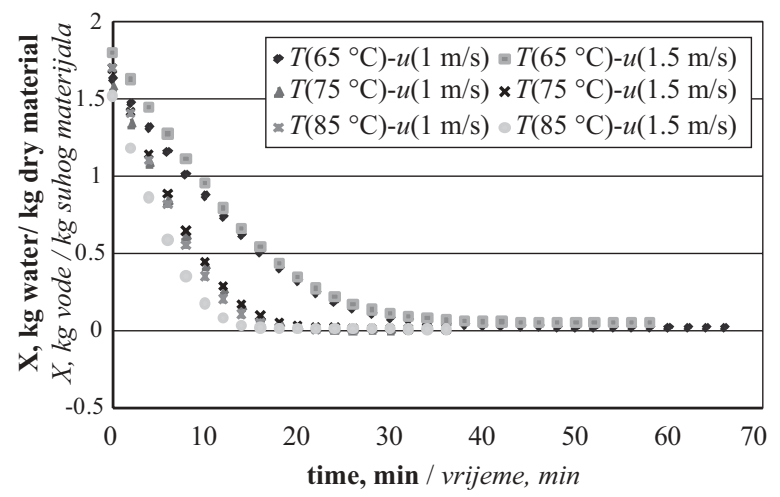

Figure 1 Drying curves (moisture content vs. time) for poplar wood particles under different hot air drying conditions

Slika 1. Krivulje sušenja (sadržaj vode u ovisnosti o vremenu sušenja) za iverje drva topole pri različitim uvjetima sušenja vrućim zrakom

shown in Figures 1-4. Numerical differentiation of the experimental drying curve data was used to obtain the drying rate curves. Poplar wood particles with an average initial moisture content of around $1.6 \mathrm{~kg}$ water $/ \mathrm{kg}$ dry material were dried to the final moisture content of about $0.008 \mathrm{~kg}$ water $/ \mathrm{kg}$ dry material. It is evident from these curves that the moisture content continuously decreased with the drying time. The drying rate was higher for wood particles dried at higher temperatures than that of particles dried at lower temperatures for the same average moisture content.

The moisture ratio of samples reduced exponentially as the drying time increased. These curves show an increase of drying rate, given by the curve slope, with an increase in temperature (Figure 1). This is in agreement with the results of the previous studies (Mazza and Maguer, 1980; Lopez at al., 2000). At higher temperatures, the relative humidity of the drying air was less than that of the drying air at lower temperatures. Hence, the difference in the partial vapor pressure between the surface of wood particles and the surrounding drying air at higher temperatures would be higher than the one at lower temperatures. Consequently, the moisture transfer rate is increased at higher temperature (Kaleemullah and Kailappan, 2005).

Figures 1 and 2 clearly show that the air temperature along with air velocity had a significant effect on the moisture content of the samples. Drying process is not only more rapid at higher temperatures but also faster at higher velocities (Figure 3). During the experiments of hot air drying, the time to reach the final moisture content for the samples was found to be between 27 and $67 \mathrm{~min}$ at different drying conditions. An increase in the air temperature and air velocity resulted in an increase in the drying rate and consequently a decrease in the drying time. Previous studies have reported similar trends (Ertekin and Yaldiz, 2004; Fritzell et al., 2009; Ghazanfari et al., 2006). As can be seen, drying rate at the initial stage of the drying period is rather low, which may be due to the activation energy and increase of the temperature of wood water content. At 


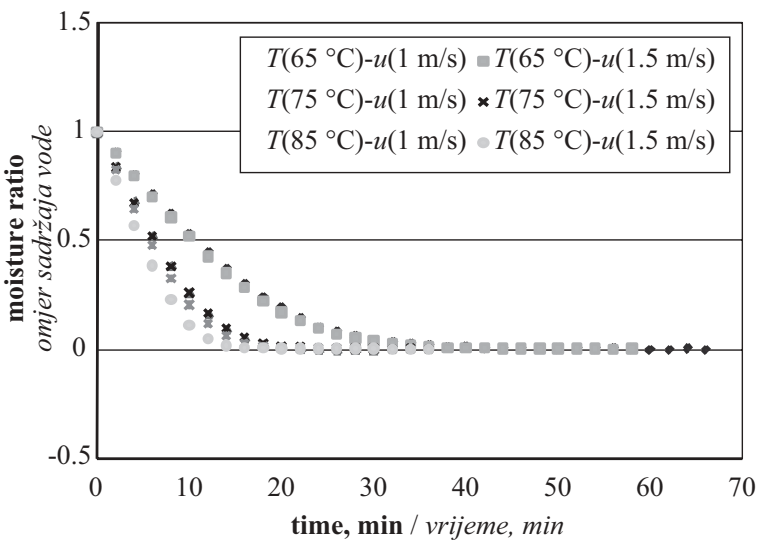

Figure 2 Drying curves (moisture ratio vs. time) for poplar wood particles under different hot air drying conditions Slika 2. Krivulje sušenja (sadržaj vode u ovisnosti o vremenu sušenja) za iverje drva topole pri različitim uvjetima sušenja vrućim zrakom

the beginning, when the moisture content was high, the drying rate was very high, and as the moisture content approached the equilibrium moisture content, the drying rate was very low (Figure 2). This is in good agreement with the results of Kaleemullah and Kailappan (2005), Lopez et al. (2000) and Mazza and Maguer (1980).

Drying rate vs. average moisture content curves (Krischer curves) for wood particles at different drying air temperatures are shown in Figure 4. To eliminate the scattering of curves, each drying rate curve was smoothed using a second-order polynomial (Kemp et al., 2001).

Generally, the product is dried at a constant rate, and for hygroscopic products, after a falling rate period, the decrease stops and the equilibrium is established. As shown in Figure 4, all drying periods can be observed in the curves for poplar wood particles made by Krischer. At the early stage of drying, known as the induction period, the wet solid temperature rises to a constant (equilibrium) value (Montazer-Rahmati and Amini-Horri, 2001) then, a short constant rate period begins. In the constant rate period of drying, external conditions such as temperature, air flow velocity, rela-

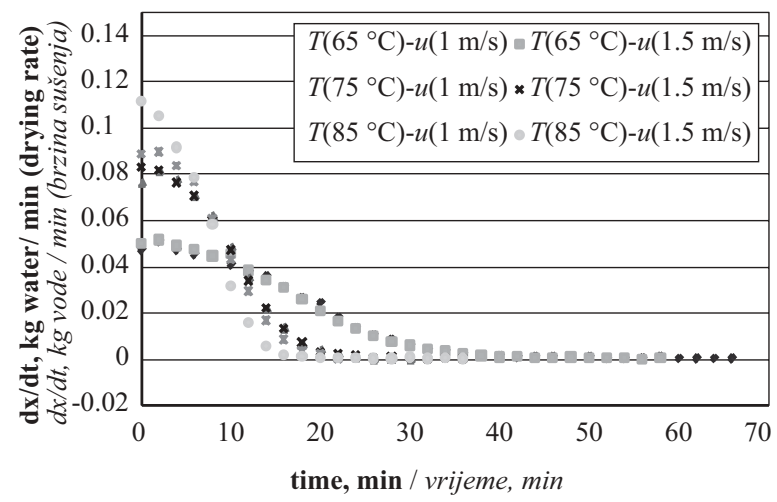

Figure 3 Drying rate curves for poplar wood particles under different hot air drying conditions

Slika 3. Krivulje brzine sušenja iverja drva topole pri različitim uvjetima sušenja vrućim zrakom tive humidity of the medium and physical form of the wood particles control the drying process and the surface diffusion is the dominant diffusion mechanism. Toward the end of the constant rate period, moisture has to be transported from the inside of the solid material to the surface by capillary forces and the drying rate may still be constant until the moisture content has reached the critical moisture content, and the surface film of the moisture has been so reduced that dry spots appear on the surface. Then the first falling rate period or unsaturated surface drying begins. Since, however, the rate is computed with respect to the overall solid surface area, the drying rate falls even though the rate per unit of wet solid surface area remains constant (Menon, 1995). In this drying period, liquid diffusion is the dominant diffusion mechanism due to moisture concentration difference and internal conditions such as moisture content, temperature, and wood particles structure. When the surface film of the liquid is entirely evaporated, the subsequent falling rate period begins. In the second falling rate period of drying, vapor diffusion is the dominant diffusion mechanism as moisture concentration difference and internal conditions are still very important (Husain et al., 1972).

Referring to the curves, the critical point is approximately $1.4 \mathrm{~kg}$ water/ $\mathrm{kg}$ dry material. This high critical moisture content is attributed to the hygroscopicity of wood substance. As mentioned above, wood particles did not show a distinct constant rate period throughout the drying process (Figure 4) and drying mostly took place in the falling rate period. Pang et al. (1997), Husain et al. (1972) and Fritzel et al. (2009) show in their investigations that there was a constant rate period during the drying of veneer and wood fibers. Bakshi and Singh (1980) state that although biological materials have high moisture content, generally no constant rate period is seen in the drying processes. Similar results have been presented by Chandy et al. (1992), Freire et al. (2001), Kaleemullah and Kailappan (2005) and Vijayaraj et al. (2007). Although materials are generally dried without a constant rate period, Erbay and Icier (2010) state that sometimes there is an overall constant rate period at the initial stages of drying. The short constant rate period that can be seen at the beginning of the drying process may be attributed to evaporation of superficial water, retained on the surface of wood particles after removing the excessive water, making the sample surfaces wet during this period.

\subsection{Fitting of the drying curves \\ 3.2. Prilagodba krivulja sušenja}

So far, numerous models have been proposed to describe the behavior of thin layer drying kinetics. In this study, four different models were fitted to the experimental drying curve data at different drying conditions (Table 1). The results of the statistical analysis and the estimated values of the parameters for these models have been listed in Table 2. The results show that all the four models gave a good fit to the experimental data with a value greater than 0.96 for $R^{2}$. Among the models, the Midilli et al. model showed the 

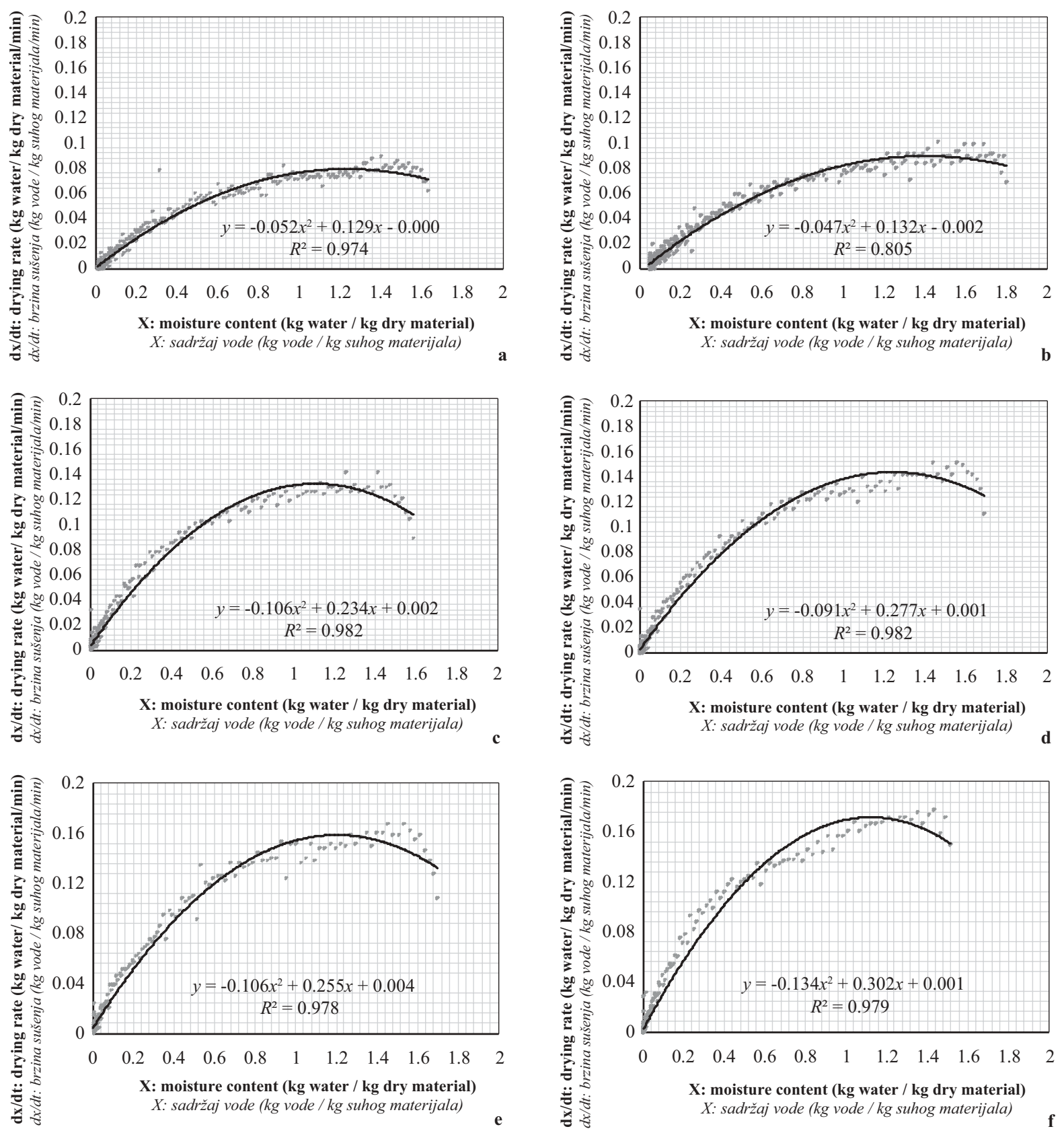

Figure 4 Krischer curves for poplar wood particles drying. a) $T=65^{\circ} \mathrm{C}, u=1 \mathrm{~m} \cdot \mathrm{s}^{-1}$; b) $T=65^{\circ} \mathrm{C}, u=1.5 \mathrm{~m} \cdot \mathrm{s}^{-1}$; c) $T=75^{\circ} \mathrm{C}$, $\mathrm{u}=1 \mathrm{~m} \cdot \mathrm{s}^{-1}$; d) $T=75^{\circ} \mathrm{C}, \mathrm{u}=1.5 \mathrm{~m} \cdot \mathrm{s}^{-1}$; e) $T=85^{\circ} \mathrm{C}, \mathrm{u}=1 \mathrm{~m} \cdot \mathrm{s}^{-1}$; f) $T=85^{\circ} \mathrm{C}, \mathrm{u}=1.5 \mathrm{~m} \cdot \mathrm{s}^{-1}$

Slika 4. Krischerove krivulje sušenja iverja drva topole: a) $T=65^{\circ} \mathrm{C}, u=1 \mathrm{~m} \cdot \mathrm{s}^{-1}$; b) $T=65^{\circ} \mathrm{C}, u=1,5 \mathrm{~m} \cdot \mathrm{s}^{-1}$; c) $T=75^{\circ} \mathrm{C}, \mathrm{u}=1$ $\mathrm{m} \cdot \mathrm{s}^{-1}$; d) $T=75^{\circ} \mathrm{C}, \mathrm{u}=1,5 \mathrm{~m} \cdot \mathrm{s}^{-1}$; e) $T=85^{\circ} \mathrm{C}, \mathrm{u}=1 \mathrm{~m} \cdot \mathrm{s}^{-1}$; f) $T=85^{\circ} \mathrm{C}, \mathrm{u}=1,5 \mathrm{~m} \cdot \mathrm{s}^{-1}$

best fit $\left(R^{2}>0.99\right)$ followed by the Page, Henderson \& Pabis and Newton models. Also, the values for RMSE, $\chi^{2}$ and $M B E$ attained from the Midilli et al. model were less than the values from other models generally followed by the Page, Henderson \& Pabis and Newton models. Therefore, the Midilli et al. model was considered the best model to represent the behavior of thin layer drying of poplar wood particles within the experimental range of this study (Table 2).

To account for the effect of the drying variables on the Midilli et al. model constants $k, a, b$ and coefficient $n$, the predicted values were correlated as a function of drying air temperature and air flow velocity using multiple regression analysis (Eqs. 9-11). Based on this analysis, the Midilli et al. model constants and coefficient were expressed in terms of drying air temperature $T\left({ }^{\circ} \mathrm{C}\right)$ and air flow velocity $u\left(\mathrm{~m} \cdot \mathrm{s}^{-1}\right)$ as:

$M R=a \cdot \exp \left(-k t^{n}\right)+b \cdot t$

$k=-0.11569+0.001718 \cdot T+0.014 \cdot u$

$a=0.9699-2.5 \cdot 10^{-5}-0.00622 \cdot u$

$n=1.3798+0.002458 \cdot T-0.0522 \cdot u$

$b=-0.00077+7.99 \cdot 10-6 \cdot T+0.000016 \cdot u$

These functions can be used to estimate the moisture ratio of poplar wood particles with a high accuracy and are valid for the above mentioned conditions. 
Table 2. Statistical analysis for the four models at different drying conditions

Tablica 2. Statistička analiza za četiri modela kinetike sušenja pri različitim uvjetima sušenja

\begin{tabular}{|c|c|c|c|c|c|c|c|}
\hline \multicolumn{2}{|c|}{$\begin{array}{l}\text { Drying condition } \\
\text { Uvjeti sušenja }\end{array}$} & \multirow[t]{2}{*}{$\begin{array}{l}\text { Model } \\
\text { Model }\end{array}$} & \multirow[t]{2}{*}{$\begin{array}{l}\text { Model parameter } \\
\text { Parametri modela }\end{array}$} & \multirow[t]{2}{*}{$R^{2}$} & \multirow[t]{2}{*}{$R M S E$} & \multirow[t]{2}{*}{$\chi^{2}$} & \multirow[t]{2}{*}{$M B E$} \\
\hline$T,{ }^{\circ} \mathrm{C}$ & $u, \mathrm{~m} \cdot \mathrm{s}^{-1}$ & & & & & & \\
\hline \multirow[t]{4}{*}{65} & \multirow[t]{4}{*}{1} & Newton & $k=0.078$ & 0.977 & 0.04263 & 0.001822 & 0.006951 \\
\hline & & Page & $k=0.028, n=1.373$ & 0.999 & 0.010607 & 0.000113 & 0.001124 \\
\hline & & Henderson \& Pabis & $a=1.119, k=0.086$ & 0.986 & 0.033157 & 0.001105 & 0.010399 \\
\hline & & Midilli et al. & $\begin{array}{l}a=0.961, k=0.021, n=1.46, \\
b=3.39 \mathrm{E}-5\end{array}$ & 0.999 & 0.00765 & $5.91 \mathrm{E}-05$ & 0.00138 \\
\hline \multirow[t]{4}{*}{65} & \multirow[t]{4}{*}{1.5} & Newton & $k=0.081$ & 0.977 & 0.043715 & 0.001917 & 0.007439 \\
\hline & & Page & $k=0.03, n=1.364$ & 0.999 & 0.00963 & $9.33 \mathrm{E}-05$ & 0.002838 \\
\hline & & Henderson \& Pabis & $a=1.117, k=0.089$ & 0.986 & 0.033799 & 0.001149 & 0.011824 \\
\hline & & Midilli et al. & $\begin{array}{l}a=0.964, k=0.023, n=1.436, \\
b=7.2 \mathrm{E}-5\end{array}$ & 1 & 0.007277 & $5.36 \mathrm{E}-05$ & 0.003065 \\
\hline \multirow[t]{4}{*}{75} & \multirow[t]{4}{*}{1} & Newton & $k=0.133$ & 0.967 & 0.054237 & 0.002957 & 0.009375 \\
\hline & & Page & $k=0.049, n=1.449$ & 0.998 & 0.054237 & 0.002973 & 0.00491 \\
\hline & & Henderson \& Pabis & $a=1.136, k=0.149$ & 0.98 & 0.042116 & 0.001793 & 0.014393 \\
\hline & & Midilli et al. & $a=0.965, k=0.04, n=1.522, b=0.0$ & 0.999 & 0.008869 & $8.03 \mathrm{E}-05$ & 0.002949 \\
\hline \multirow[t]{4}{*}{75} & \multirow[t]{4}{*}{1.5} & Newton & $k=0.135$ & 0.974 & 0.045899 & 0.002116 & 0.009049 \\
\hline & & Page & $k=0.055, n=1.405$ & 0.998 & 0.011272 & 0.000128 & 0.004173 \\
\hline & & Henderson \& Pabis & $a=1.123, k=0.15$ & 0.984 & 0.036185 & 0.001321 & 0.011928 \\
\hline & & Midilli et al. & $\begin{array}{l}a=0.959, k=0.043, n=1.497, \\
b=9.6 \mathrm{E}-5\end{array}$ & 0.999 & 0.007993 & $6.50 \mathrm{E}-05$ & 0.00018 \\
\hline \multirow[t]{4}{*}{85} & \multirow[t]{4}{*}{1} & Newton & $k=0.149$ & 0.967 & 0.054877 & 0.00303 & 0.008771 \\
\hline & & Page & $k=0.059, n=1.438$ & 0.998 & 0.01267 & 0.000163 & 0.005302 \\
\hline & & Henderson \& Pabis & $a=1.132, k=0.166$ & 0.998 & 0.042968 & 0.001869 & 0.014854 \\
\hline & & Midilli et al. & $a=0.965, k=0.049, n=1.505, b=0.0$ & 0.999 & 0.009844 & 9.94E-05 & 0.003714 \\
\hline \multirow[t]{4}{*}{85} & \multirow[t]{4}{*}{1.5} & Newton & $k=0.181$ & 0.975 & 0.041127 & 0.001699 & 0.007482 \\
\hline & & Page & $k=0.081, n=1.413$ & 0.998 & 0.012093 & 0.000148 & 0.004051 \\
\hline & & Henderson \& Pabis & $a=1.121, k=0.20$ & 0.984 & 0.033194 & 0.001112 & 0.009962 \\
\hline & & Midilli et al. & $\begin{array}{l}a=0.952, k=0.062, n=1.528, \\
b=5.45 \mathrm{E}-5\end{array}$ & 0.999 & 0.0092 & $8.62 \mathrm{E}-05$ & 0.000312 \\
\hline
\end{tabular}

The accuracy of the established model was evaluated by comparing the computed moisture ratios with the observed values as shown in Figure 5. The close agreement between the measured and the predicted moisture contents gives confidence in applying the mo-

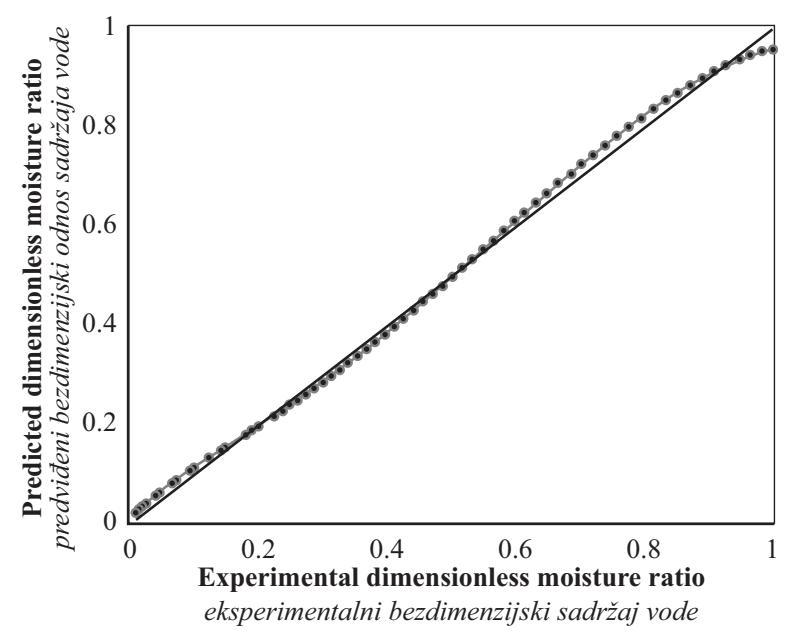

Figure 5 Experimental moisture ratio vs. predicted moisture ratio from Midilli et al. model for constant $T=85^{\circ} \mathrm{C}$, $u=1.5 \mathrm{~m} \cdot \mathrm{s}^{-1}$

Slika 5. Eksperimentalni sadržaj vode u odnosu na predviđeni omjer sadržaja vode prema modelu Midillija i suradnika za konstante $T=85^{\circ} \mathrm{C}, u=1,5 \mathrm{~m} \cdot \mathrm{s}^{-1}$ del to examine the influence of wood particles variables and drying conditions on the drying rate.

\subsection{Calculation of effective moisture diffusivity} and activation energy of diffusion

3.3. Izračun efektivne difuznosti vode u drvu i aktivacijske energije difuzije

In describing a drying process during the falling rate period, the concept of effective moisture diffusivity $\left(D_{\text {eff }}\right)$ has been accepted as the basic mechanism of moisture movement inside the drying material (Reyes et al. 2004). As mentioned in the previous sections, the drying of wood particles mostly occurs in the falling rate period and liquid diffusion controls the process. Fick's second law of diffusion can be used to model the drying behavior of wood particles. The following analytical solution for diffusion in an infinite planar slab was given by Akpinar, 2006:

$$
M R=\frac{M}{M_{o}}=\frac{8}{\pi^{2}} \sum_{n=1}^{\infty} \frac{1}{(2 n-1)^{2}} \exp \left[-\frac{(2 n-1)^{2} \pi^{2} D t}{4 L^{2}}\right]
$$

Only the first term of equation (6) is used for long drying times (Lopez et al., 2000), hence:

$$
M R=\frac{8}{\pi^{2}} \exp \left[-\frac{\pi^{2} D t}{4 L^{2}}\right]
$$




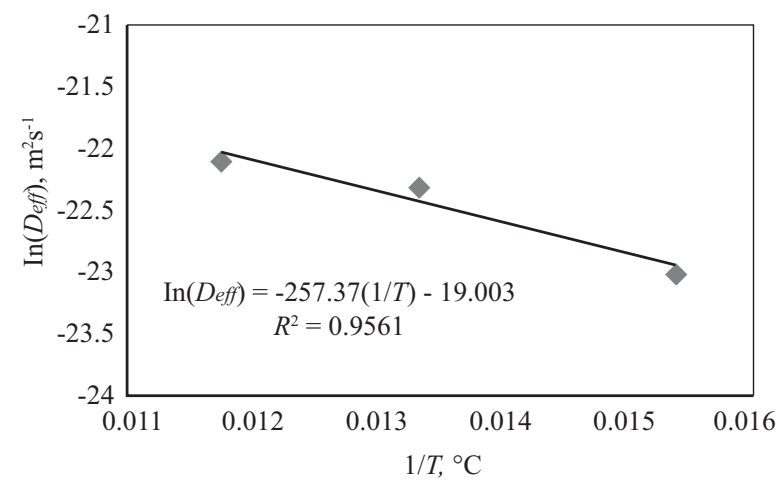

Figure 6 Relationship between the effective moisture diffusivity $\left(D_{e f f}\right)$ and the reciprocal of absolute temperature $(1 / T)$

Slika 6. Odnos između efektivne difuznosti vode u drvu $\left(D_{e f f}\right)$ i recipročne vrijednosti apsolutne temperatura $(1 / T)$

From equation (7), a plot of $\ln (M R)$ versus time gives a straight line with a slope of $k_{o}$ given by:

$$
k_{0}=\frac{\pi^{2} D}{4 L^{2}}
$$

The activation energy of diffusion was calculated using an Arrhenius type equation (Akpinar et al., 2003; Lopez et al., 2000):

$$
D=D_{0} \exp \left[-\frac{E_{a}}{R T_{a}}\right]
$$

Where $E_{a}$ is the energy of activation $\left(\mathrm{kJ} \cdot \mathrm{mol}^{-1}\right), R$ is universal gas constant $\left(8.3143 \mathrm{~kJ} \cdot \mathrm{mol}^{-1} \mathrm{~K}\right), T$ is absolute air temperature $(K)$, and $D_{o}$ is the pre-exponential factor of the Arrhenius equation $\left(\mathrm{m}^{2} \cdot \mathrm{s}^{-1}\right)$. The activation energy can be determined from the slope of the Arrhenius plot, $\ln (D)$ versus $1 / T_{a}$. From Equation (9), a plot of $\ln (D)$ versus $1 / T_{a}$ gives a straight line whose slope is $k_{1}$, given by:

$$
k_{1}=\frac{E_{a}}{R}
$$

In the above equations, isothermal assumption was used and $T$ is the ambient air temperature of the dryer duct.

The effective moisture diffusivity $D_{\text {eff }}$ of poplar wood particles increased from $1.01 \mathrm{E}-10$ to $2.53 \mathrm{E}-10$ $\mathrm{m}^{2} \cdot \mathrm{s}^{-1}$ as the drying air temperature increased from 65 to $85^{\circ} \mathrm{C}$, and increased from $1.69 \mathrm{E}-10$ to $2.03 \mathrm{E}-10 \mathrm{~m}^{2} \cdot \mathrm{s}^{-1}$ as the air flow velocity increased from 1 to $1.5 \mathrm{~m} \cdot \mathrm{s}^{-1}$. As can be deduced, the effect of hot air temperature on effective moisture diffusivity is higher than that of air flow rate. The plot depicting the relationship between $\ln \left(D_{\text {eff }}\right)$ and $1 / T$ was found to be a straight line in the range of temperatures investigated, indicating Arrhenius dependence (Figure 6). The activation energy of diffusion $E_{a}$ for $1 \mathrm{~m} \cdot \mathrm{s}^{-1}$ and $1.5 \mathrm{~m} \cdot \mathrm{s}^{-1}$ air velocity were also calculated as $27.8 \mathrm{~kJ} \cdot \mathrm{mol}^{-1}$ and $50.8 \mathrm{~kJ} \cdot \mathrm{mol}^{-1}$, respectively.

\section{CONCLUSION \\ 4. ZAKLJUČAK}

At the end of this study, the following conclusions can be drawn:
The Midilli et al. model is quite suitable for predicting the drying curve behavior of poplar wood particles in the temperature range of $65-85^{\circ} \mathrm{C}$.

Constant drying rate period is very short in any of the experiments and the drying process of the poplar wood particles is mostly carried out at the falling rate period.

Effective moisture diffusivity of poplar wood particles increases with increasing air temperature and air flow velocity in the range of $1.01 \mathrm{E}-10$ to $2.53 \mathrm{E}-10 \mathrm{~m}^{2} \cdot \mathrm{s}^{-1}$.

The activation energy of diffusion for $1 \mathrm{~m} \cdot \mathrm{s}^{-1}$ and $1.5 \mathrm{~m} \cdot \mathrm{s}^{-1}$ air flow velocities were calculated as 27.8 $\mathrm{kJ} \cdot \mathrm{mol}^{-1}$ and $50.8 \mathrm{~kJ} \cdot \mathrm{mol}^{-1}$, respectively.

\section{NOMENCLATURE}

\section{OPIS ZNAKOVA}

$a, n, b$ Dimensionless drying constants in drying models / bezdimenzionalne konstante u modelima sušenja

$k \quad$ Drying velocity constant in drying models $\left(\mathrm{min}^{-1}\right)$ / konstanta brzine sušenja u modelima sušenja

L Particles half thickness (m) / polovica debljine iverja

M Moisture content at any time (\% dry basis) (kg water/ kg dry material) / trenutačni sadržaj vode (\% u odnosu prema suhome materijalu) (kg vode / kg suhog materijala)

$M B E$ Mean bias error/srednja pogreška

$M R$ Moisture ratio / omjer sadržaja vode

$R \quad$ Universal gas constant $\left(8.3143 \mathrm{~kJ} \mathrm{~mol}^{-1} \cdot \mathrm{K}^{-1}\right) /$ opća plinska konstanta

$N \quad$ Total number of observation / ukupni broj zapažanja

$n \quad$ Number of constants / broj konstanti

$n \quad$ Number of terms / broj uvjeta

$R^{2} \quad$ Coefficient of determination / koeficijent determinacije

RH Relative humidity in drying chamber / relativna vlažnost zraka u sušionici

RMSE Root mean square error / korijen srednje kvadratne pogreške

$D \quad$ Diffusivity $\left(\mathrm{m}^{2} \cdot \mathrm{s}^{-1}\right) /$ difuznost

E Energy $\left(\mathrm{kJ} \cdot \mathrm{mol}^{-1}\right) /$ energija

$T$ Temperature $\left({ }^{\circ} \mathrm{C}\right)\left({ }^{\circ} \mathrm{K}\right) /$ temperatura

$t \quad$ Time $(\mathrm{min}) /$ vrijeme

$u \quad$ Air flow velocity $\left(\mathrm{m} \cdot \mathrm{s}^{-1}\right) /$ brzina strujanja zraka

$x \quad$ Moisture content ( $\mathrm{kg}$ water / $\mathrm{kg}$ dry material) / sadržaj vode u drvu ( $\mathrm{kg} /$ vode / $\mathrm{kg}$ suhog materijala) Greek symbols

$\chi^{2} \quad$ Reduced chi- square / reducirani Hi-kvadrat Subscripts

$0 \quad$ Initial / početno stanje

$i \quad i$ th order / $i$-ti red

crit Critical / kritično

e Equilibrium / ravnoteža

exp Experimental / eksperimentalni

a Activation / aktivacija

a Air / zrak

eff Effective / efektivno

$m \quad$ Mean / prosječno

pre Predicted/predvideno 


\section{REFERENCES}

\section{LITERATURA}

1. Akpinar, E. K. 2006: Determination of suitable thin layer drying curve model for some vegetables and fruits. J. Food Eng. 73:75-84 http://dx.doi.org/10.1016/j.jfoodeng.2005.01.007.

2. Akpinar, E. K.; Midilli, A.; Bicer, Y., 2003: Single layer drying behavior of potato slices in a convective cyclone and mathematical modeling. Energy Conversion Manage 44:1689-1705 http://dx.doi.org/10.1016/S0196-8904(02)00171-1.

3. ASAE, 2001: Moisture Relationships of Plant-Based Agricultural Products. D245.5.

4. Bakshi, A. S.; Singh, R. P., 1980: Drying Characteristics of parboiled rice. In: Drying'80; Mujumdar, A S Eds.; Hemisphere Publishing Company. Washington DC.

5. Brooker, D. B.; Bakker-Arkema, F. W.; Hall, C. W., 1974: Drying Cereal Grains. Westport, Conn., AVI Publishing Co.

6. Ceylan, I., 2008: Determination of Drying Characteristics of Timber by Using Artificial Neural Networks and Mathematical Models. Dry. Technol. 26:1469-1476 http://dx.doi.org/10.1080/07373930802412132.

7. Chandy, E.; Ilyas, S. M.; Samuel, D. V. K.; Singh, A., 1992: Effect of some physical treatments on drying characteristics of red chilies. Proceedings of the International Agricultural Engineering Conference. Bangkok. Thailand 489-498.

8. Chninman, M. S., 1984: Evaluation of selected mathematical models for describing thin layer drying of in-shell pecans. Transactions of the ASAE 27:610-615.

9. Erbay, Z.; Icier, F., 2010: A review of thin layer drying of foods: Theory, Modeling, and Experimental Results. Critical Reviews in Food Science and Nutrition 50(5):441464 http://dx.doi.org/10.1080/10408390802437063.

10. Ertekin, C.; Yaldiz, O., 2004: Drying of eggplant and selection of a suitable thin layer drying model. J. Food Eng. 63 (3):349-359 http://dx.doi.org/10.1016/j.jfoodeng.2003.08.007.

11. Freire, F.; Figueiredo, A.; Ferrao, P., 2001: Modelling High Temperature Thin Layer Drying Kinetics of Olive Bagasse. J. Agri. Eng. Res. 78 (4):397-406 http://dx.doi.org/10.1006/jaer.2000.0657.

12. Fyhr, C.; Rasmuson, A., 1996: Mathematical model of steam drying of wood chips and other hygroscopic porous media. AICHE Journal 42 (9):2491-2502 http://dx.doi.org/10.1002/aic.690420909.

13. Fritzell, E.; Melander, O.; Rasmuson, A., 2009: The Drying Kinetics and Equilibrium Moisture Content of MDF Fibers. Dry. Technol. 27 (9):993-998 http://dx.doi.org/10.1080/07373930902904566.

14. Ghazanfari, A.; Emami, S.; Tabil, L. G.; Panigrahi, S., 2006: Thin-Layer Drying of Flax Fiber: II. Modeling Drying Process Using Semi-Theoretical and Empirical Models. Dry. Technol. 24:1637-1642 http://dx.doi.org/10.1080/07373930601031463.

15. Guarte, R. C., 1996: Modeling the drying behavior of copra and development of a natural convection dryer for production of high quality copra in the Philippines. $\mathrm{PhD}$ Dissertation. Hohenheim. Stuttgart. Germany.

16. Husain, A.; Chen, C. S.; Clayton, J. T.; Whitney, L. F., 1972: Mathematical simulation of mass and heat transfer in high moisture foods. Transactions of the ASAE 15:732736 .
17. Kaleemullah, S.; Kailappan, R., 2005: Drying Kinetics of Red Chillies in a Rotary Dryer. Biosys. Eng. 92 (1):15-23 http://dx.doi.org/10.1016/j.biosystemseng.2005.05.015.

18. Kemp, I. C.; Fyhr, B. C.; Laurent, S.; Roques, M. A.; Groenewold, C. E.; Tsotsas, E.; Sereno, A. A.; Bonazzi, C. B.; Bimbenet, J. J.; Kind, M., 2001: Methods for processing experimental drying kinetics data. Dry. Technol. 19 (1):15-34 http://dx.doi.org/10.1081/DRT-100001350.

19. Lopez, A.; Iguaz, A.; Esnoz, A.; Virseda, P., 2000: Thinlayer drying behavior of vegetable wastes from wholesale market. Dry. Technol. 18(4-5):995-1006 http://dx.doi.org/10.1080/07373930008917749.

20. Mazza, G.; Maguer, M. L., 1980: Dehydration of onion: some theoretical and practical considerations. J. Food Technol. 15:181-194 http://dx.doi.org/10.1111/j.1365-2621.1980.tb00930.x.

21. Menon, A. S., 1995: Drying of Solids: Principles, Classification, and Selection of Dryers in: A. S.Mujumdar (Eds.). Handbook of Industrial Drying.

22. Midilli, A.; Kucuk, H.; Yapar, Z., 2002: A new model for single-layer drying. Dry. Technol. 20 (7):1503-1513.

23. Montazer-Rahmati, M. M.; Amini-Horri, B., 2005: From Laboratory Experiments to Design of a Conveyor-Belt Dryer via Mathematical Modeling. Dry. Technol. 23 (12):2389-2420

http://dx.doi.org/10.1080/07373930500340460.

24. O'Callaghan, J. R.; Menzies, D. J.; Bailey, P. H., 1971: Digital simulation of agricultural dryer performance. J. Agri. Eng. Res. 6 (3):223-244 http://dx.doi.org/10.1016/S0021-8634(71)80016-1.

25. Omid, M.; Baharlooei, A.; Ahmadi, H., 2009: Modeling Drying Kinetics of Pistachio Nuts with Multilayer FeedForward Neural Network. Dry. Technol., 27 (10): 10691077 http://dx.doi.org/10.1080/07373930903218602.

26. Page, C., 1949: Factors Influencing the Maximum Rate of Drying Shelled Corn in Layers. M.S. Thesis; Purdue University; West Lafayette; Indiana.

27. Pang, S.; Riley, S. G.; Haslett, A. N., 1997: Simulation of pinus radiata veneer drying: Moisture content and temperature profiles. For. Prod. J. 47 (7-8):51-58.

28. Reyes, A.; Eckholt, M.; Troncoso, F.; Efremov. G., 2004: Drying Kinetics of Sludge from a Wastewater Treatment Plant. Dry. Technol. 22 (9):2135-2150 http://dx.doi.org/10.1081/DRT-200034218.

29. Vijayaraj, B.; Saravanan, R.; Renganarayanan, S., 2007: Studies on Thin Layer Drying of Bagasse (short communication). Int. J. Energy Res. 31:422-437 http://dx.doi.org/10.1002/er.1237.

\section{Corresponding address:}

\section{Prof. HAMID ZAREA HOSSEINABADI, Ph.D.}

Department of Wood and Paper Sciences

and Technology

Faculty of Natural Resources

University of Tehran

P.O Box: 315854314

Karaj, IRAN

E-mail: hzareah@ut.ac.ir, zare.hamid@gmail.com 